\title{
Aviation piston engines on-condition maintenance - proposal
}

\begin{abstract}
The article presents a proposal of the established in the Institute of Aviation program and tools that are to enable General Aviation Operators in our country to perform on-condition maintenance of piston engines. Program apart from the existing (strictly supervised) Engine Manual tasks, introduces new mandatory maintenance activities such as: monitoring of engine parameters during cruise and climb, with determination of their diagnostic tolerance limits (never been performed in the maintenance practice), oil spectrographic analysis, also with determination of tolerances and oil particle size monitoring. The article shows results of half year long monitored exploitations of Continental IO-240-B engines installed on Diamond DA20-C1 „Katana” aircraft.
\end{abstract}

Key words: on-condition maintenance, piston engine, engine condition monitoring

\section{Eksploatacja lotniczych silników tłokowych według stanu technicznego - propozycja}

Artykut prezentuje opracowana w Instytucie Lotnictwa koncepcję umożliwiająca operatorom lotnictwa ogólnego w Polsce eksploatację lotniczych silników tłokowych wedtug stanu technicznego. Program obsługi, oprócz ściśle monitorowanych obowiąujących już czynności obstugowych wprowadza nowe, jak: zapis i monitorowanie parametrów pracy silnika podczas wznoszenia i lotu poziomego z wyznaczeniem ich granic tolerancji diagnostycznej, analize spektrograficzna oleju silnikowego z wyznaczeniem dopuszczalnych wielkości zawartości charakterystycznych pierwiastków i monitorowanie wielkości opiłków ferromagnetycznych. W artykule przedstawiono rezultaty nadzorowanej pótrocznej eksploatacji silników IO-240-B firmy Continental zainstalowanych na samolotach Diamond DA20-C1 „Katana”.

Słowa kluczowe: eksploatacja według stanu technicznego, silnik tłokowy, monitorowanie stanu technicznego silnika

\section{Preface}

Appropriate engine exploitation is most important for the reliable performance and thus high level of flight safety. Possibility of the engine TBO extension and more importantly the introduction of their on-condition maintenance is the main cause of forcing a high level of aircraft engine exploitation. The first objective of this article is to present arguments supporting above mentioned thesis. The second objective is the presentation of maintenance on-condition concept of the aviation piston engines established at the Institute of Aviation

\section{Introduction}

At present in many countries aviation safety regulations allow exploitation of piston engines above recommended TBO. For example, UK CAA in the CAP 747, which applies mandatory requirements for airworthiness, contains so called Generic Requirement No 24 (GR No 24). The document determines conditions for extension of overhaul periods of light aircraft piston engines. A light aircraft is one whose maximum takeoff mass (MTOM) is less than $2730 \mathrm{~kg}$, while engine installed in the aircraft has power not exceeding 400 $\mathrm{hp}(298 \mathrm{~kW})$. Many types of the engines, however, are excluded from the program, mainly due to a lack of sufficient service experience.

Upon fulfilment of certain requirements $20 \%$ TBO extension is granted, for some engines with no limits. Generally, the condition for continued operation is strict adherence to manufacturer manuals and documentation of subsequent inspections.

\section{Wprowadzenie}

Odpowiednie utrzymanie i użytkowanie silnika są najistotniejszymi elementami w zapewnieniu jego niezawodnej pracy, a tym samym wysokiego poziomu bezpieczeństwa wykonywania lotów. Możliwość przedłużenia okresu międzyremontowego silników, a tym bardziej wprowadzenie ich eksploatacji według stanu technicznego, są główną przyczyną wymuszającą wysoki poziom eksploatacji zespołów napędowych samolotu. Przedstawienie argumentów wspierających powyższą tezę jest pierwszym celem tego artykułu. Drugim - przedstawienie propozycji programu eksploatacji lotniczych silników tłokowych według stanu technicznego opracowanego w Instytucie Lotnictwa.

\section{Wstęp}

Obecnie w wielu krajach przepisy dotyczące bezpieczeństwa lotniczego pozwalają na eksploatację silników tłokowych bez ograniczania okresu międzyremontowego. Na przykład: Lotniczy Nadzór Państwowy Wielkiej Brytanii w dokumencie CAP 747 dotyczącym obowiązkowych wymagań zdatności do lotu zawarł tzw. wymagania generyczne nr 24. Standardy te określają, jakim silnikom tłokowym zabudowanym na tzw. samolotach lekkich i na jakich warunkach możliwe jest wydłużenie okresu pomiędzy remontami. Samoloty lekkie mają maksymalną masę do startu mniejszą niż $2730 \mathrm{~kg}$, a silniki na nich zabudowane nie przekraczają $298 \mathrm{~kW}$ (400 KM) mocy. Wiele typów silników wyłączonych jest jednak z programu, głównie $\mathrm{z}$ powodu braku wystarczającego doświadczenia w ich eksploatacji. 
Similar legislation has been introduced by other worldwide NAA's from Australia to Botswana.

Summarizing: NAA's have approved exploitation of piston engines to something like quasi on-condition maintenance, but without new technical requirements in addition to those already included in the manufacturers documentation.

\section{How is engine TBO determined}

The TBO for an engine commonly referred to as "hard time" is usually established by the manufacturers carrying out test-bed endurance programs where the engine is run day and night, cycling through a specified and purposely over-punishing schedule of so many hours at full power, so many at idle, so many at cruise. During the manufacturer's tests the engine is run on the test bed in a manner which is purposely more severe than ordinary operator will use.

The tests do not take into account the damage that occurs due to aircraft being very little used through the winter, when over time the oil film breaks down and internal corrosion takes hold, aided and abetted by internal condensation and the combustion products having turned the old oil acidic. The above mentioned facts support opinion that TBO is the engine manufacturer's best shot at saying how long he thinks the engine should run reliably [5]. Most manufacturers specify a calendar life as well as hours of operation, and with the low utilisation, the calendar life often 'runs out' long before the hours have reached their TBO limit.

Condition of the engine is largely dependent on how the pilot uses it, technical staff maintenance and storage, types of oil and fuel that is used as much as the time or hours it operates.

\section{Aviation piston engine}

Aviation piston engines are characterized by their large displacement and supercharging, which improves initial cycle parameters, therefore compression levels of these engines are low and mainly are in the range $\varepsilon=6-8$. Increasing level of compression, in spite of its benefits is limited by possible detonation caused by intense heat and pressure at the compression end cycle. Higher compression could also cause the engine mass increase which is unacceptable in aviation.

\subsection{Engine basic components - exploitation remarks}

Piston engine consists of many parts, whose faultless operation enables its high level of reliability and durability. However decisive for the engine technical condition are: crankshaft system and their bearings, camshaft, cylinders and crankcase. These components condition has influence on possible TBO extension. Internal engine parts are cooled by oil. Pistons are cooled by oil and heat dissipation through cylinders. However the highest thermal loads affect the cylinders and cylinders heads, but these parts are cooled by air.

Baffles and their shape are important to keep proper direction of cooling air flow around cylinders. It is important to keep correct and properly fitting baffles throughout the whole time of the aircraft operation. Picture 1 shows cooling air flow around engine cylinders. Engine operational ratings
Po spełnieniu określonych wymagań wyrażana jest zgoda na 20-procentowe przedłużenie okresu międzyremontowego dla części silników bez jakichkolwiek ograniczeń. Ogólnie, warunkiem przedłużenia czasu eksploatacji jest ścisłe przestrzeganie instrukcji obsługi i dokumentowanie kolejnych przeglądów technicznych. Podobne dokumenty wydały cywilne lotnicze nadzory wielu państw, od Australii po niektóre kraje afrykańskie.

Podsumowując: nadzory lotnicze zaaprobowały eksploatację silników tłokowych według quasi- stanu technicznego, lecz bez wymagania dodatkowych czynności ponad te zawarte $\mathrm{w}$ instrukcjach producenta.

\section{Jak wyznaczany jest okres międzyremontowy silnika}

Okres międzyremontowy, potocznie nazywany też resursem silnika, zazwyczaj określony jest przez producenta po przeprowadzeniu długotrwałych sprawdzeń na stacji prób. Pracuje on na niej dzień i noc w bardzo wymagającym cyklu, w którym na zakres startowy, przelotowy czy biegu jałowego przypada określony czas pracy.

Podczas prób w zakładzie produkcyjnym silniki,z jednej strony, celowo są poddawane większym obciążeniom termicznym niż te występujące podczas rzeczywistej eksploatacji u użytkownika. Z drugiej strony nie jest brana pod uwagę sezonowość. Zimą samoloty na ogół nie są wykorzystywane i w tych warunkach w silniku następuje przerwanie powłoki olejowej, co prowadzi do tworzenia się korozji. Zjawisko to potęgowane jest wzrostem stężenia produktów spalania, negatywnie wpływających na kwasowość oleju. Ten sposób wyznaczania resursu nie uwzględnia rzeczywistych warunków eksploatacji.

Stan techniczny silnika zależy bardziej od sposobu użytkowania przez pilota, obsługiwania i przechowywania przez personel techniczny, od typów stosowanego oleju i paliwa niż od czasu lub godzin jego pracy. Powyższe wspiera opinię, że okres międzyremontowy jest najlepszym przybliżeniem producenta określającym czas niezawodnej pracy silnika [5].

Większość producentów poleca okres międzyremontowy w latach i godzinach pracy silnika. Mało intensywna eksploatacja samolotu powoduje, że kalendarzowy czas pracy może znacznie wyprzedzić godzinowy.

\section{Lotniczy silnik tlokowy}

Tłokowe silniki lotnicze charakteryzują się dużymi objętościami cylindrów i stosowaniem doładowania. Podwyższa ono wielkość parametrów początkowych obiegu, dlatego ich stopnie sprężania są niewielkie i zawierają się przedziale $\varepsilon=6-8$.

Zwiększenie stopnia sprężania, mimo wynikających z tego korzyści, jest ograniczone możliwością występowania spalania detonacyjnego (stukowego) przy zbyt wysokich ciśnieniach i temperaturach końca sprężania. Zwiększenie stopnia sprężania powodowałoby również znaczny, nie do zaakceptowania w lotnictwie, wzrost masy silnika. 
have to be kept such that there are no excessive crankshaft loads caused by forced vibrations.

Low power and simple design engines, often have time limitations for operation on certain shaft speeds specified by the designer.

Proper work of all cylinders has a significant impact on preventing the occurrence of forced vibrations.

At present camshaft train has hydraulic lifters, which are always keeping the required valves clearances, thus only faulted spark plug can cause an increase in vibrations. Hence, on top of the safety reasons, aviation engines use two spark plugs per cylinder.

Dumping force of torsional vibrations of crank system mainly depends on engine oil viscosity, which through hours of operations becomes lower.

It is important to follow manufacturer manual requirements for frequencies of oil changes (mostly every 50 hours).

Engine reliability and durability are dependent on assembly quality, of course this is the role of manufacturers and overhaul facilities. However, in direct operation the precision of assembly of certain components and aggregates also affects the condition of the entire powertrain.

During engine units changes technical staff has to pay particular attention to proper screw tightening and securing them as well as connection of the tubes (oil, air, fuel) and electrical wires. Special attention is required in spark plug and fuel pump installation due to their correct positioning relative to the position of the crankshaft.

Inspection of the screws and bolts connections takes a lot of time for maintenance personnel. The main cause of connections loosening is the stress relaxation phenomenon.

Technicians have to be aware that such a problem is observed in stored engines as well. Before engine installation bolts, nuts and screws torques must be inspected. Values of

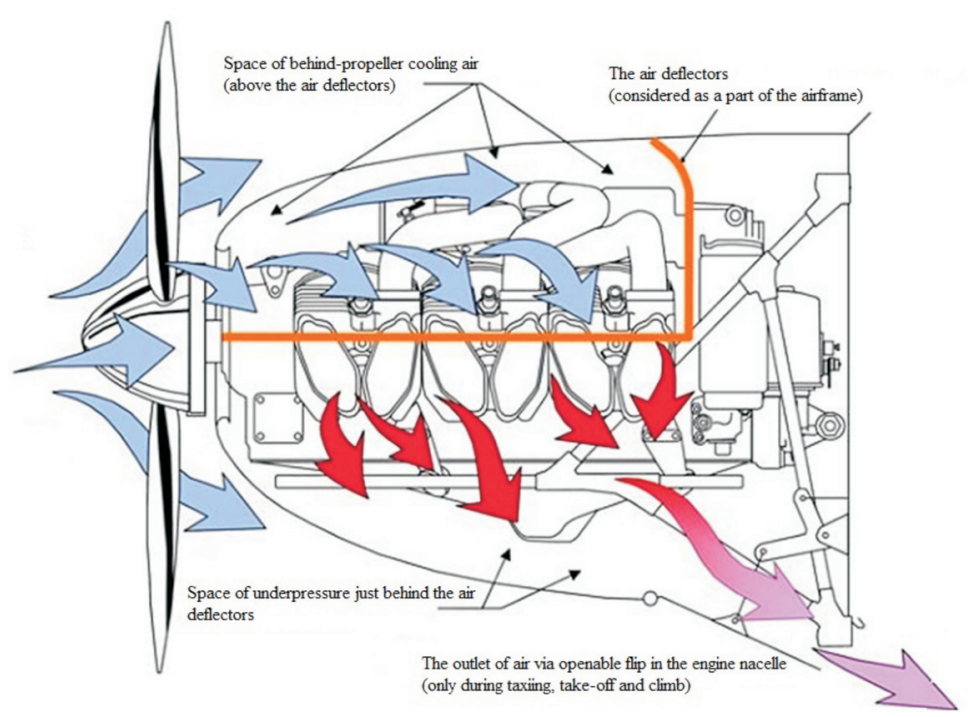

Fig. 1. The scheme of the baffles arrangement and the cooling air flow in the engine compartment [10]

Rys. 1. Rozmieszczenie deflektorów i schemat przepływu strumienia powietrza chłodzacego w przedziale silnikowym [10]

\subsection{Podstawowe zespoły silnika - uwagi eksploatacyjne}

Silnik tłokowy składa się z wielu części i elementów, których prawidłowa praca wpływa na niezawodność i żywotność całego zespołu napędowego. Decydujące jednak o stanie technicznym silnika (wiążące się z możliwością przedłużenia ponad limitowany dokumentacją producenta czas jego pracy) są: układ korbowy i jego łożyska, rozrząd, cylindry i karter.

Wszystkie części wewnętrzne silnika chłodzone sa olejem. Tłoki chłodzone są olejem oraz za pośrednictwem odprowadzania ciepła do cylindrów. Jednakże podzespoły najbardziej narażone na działanie wysokich temperatur, jak cylindry i ich głowice, chłodzone są bezpośrednio strumieniem powietrza atmosferycznego opływającego silnik. Kierunek chłodzącego strumienia powietrza atmosferycznego ustalony jest odpowiednim kształtem deflektorów znajdujących się w przedziale silnikowym, dlatego tak ważne jest utrzymywanie ich geometrii w idealnym stanie przez cały okres eksploatacji samolotu. Na rysunku 1 przedstawiono wymuszony deflektorami przepływ chłodzącego powietrza wokół cylindrów silnika.

Zakresy pracy w czasie eksploatacji silnika lotniczego powinny być takie, by nie pojawiały się nadmierne obciążenia wału korbowego spowodowane wymuszonymi drganiami. Silniki o małej mocy i prostej konstrukcji często mają ograniczenie dłuższej pracy na określonej przez konstruktora prędkości obrotowej.

Istotny wpływ na pewność niewystąpienia silnych drgań wymuszonych silnika ma właściwa praca wszystkich cylindrów. W związku z tym, że obecnie silniki wyposażone są w hydrauliczne kompensatory luzu zaworowego, niewłaściwie pracująca świeca zapłonowa może być przyczyną drgań. Dlatego oprócz przyczyn wynikających z bezpieczeństwa, w lotniczych silnikach tłokowych stosuje się dwie świece zapłonowe w każdym cylindrze.

Momenty thumiące drgania skrętne układów korbowych zależą w dużym stopniu od lepkości stosowanego oleju. Ze wzrostem nalotu (godzin pracy silnika) lepkość oleju zmniejsza się, dlatego tak ważna jest jego wymiana zgodnie $\mathrm{z}$ wymaganiami producenta (najczęściej co 50 godzin).

Niezawodność pracy silnika i jego żywotność w dużym stopniu zależą od jakości jego montażu. Dotyczy to organizacji produkujących silniki i wyposażenia zakładów remontowych. Jednak w bezpośredniej eksploatacji dokładność montażu niektórych podzespołów i agregatów ma również wpływ na stan techniczny całego zespołu napędowego. Wymiana agregatów występuje dość często w praktyce obsługowej. Wymaga ona uwagi personelu obsługującego, szczególnie przy dokręcaniu śrub, ich zabezpieczaniu i podłączaniu do agregatów przewodów (olejowych, powietrznych, paliwowych i elektrycznych).

Wiele uwagi wymaga montaż iskrowników i wtryskowych pomp paliwowych ze względu 
the torques are given for items manufactured from certain material and hasty usage of replacements made from other materials is not allowed.

\subsection{TBO extension conditions}

Experience of aviation industry gives confidence that:

- strict adherence to the manuals procedures

- high level of technical culture

- engine condition monitoring

allows engine exploitation far above TBO recommended by the manufacturer without running the risk of sudden failure during flight.

Not all engines are suitable for running beyond TBO, due to known by aviation industry problems like: corrosion and spalling of camshafts of one of the manufacturers or crankshaft fatigue failure of other one.

In order to extend TBO, NAA's require as mentioned in chapter 2 compliance with several conditions. Also some checks included in manuals have to be carried out.

Those are:

a) the overhaul history of the engine

b) the maintenance history

c) the quality of the maintenance records

d) the kind of life it has led since overhaul - accidents, periods of neglect etc.

e) evaluation of inspection results according to maintenance program

f) engine configuration (modification status, PMA parts etc.)

g) engine type (with fuel injection, supercharged, carburetor)

h) type of the propeller powered by engine

i) aircraft utilization e.g. acrobatic

j) results of special inspection and engine run performed before decision for TBO extension

For the most of aviation piston engines basic inspection is 100 hours check. There are several inspection tasks included in it, those are:

1. Cylinder differential pressure

2. Each cylinder compression

3. Each cylinder BSI

4. Baffles condition

5. Oil filter

6. Magnetic chip detector (if installed)

7. Oil spectrographic analysis

8. Oil consumption

Points 5-8 are carried out every 50 hours. 100 hours check is ended by special engine run, where the following parameters have to be noted:

1. Maximum static rpm

2. Oil pressure at idle

3. Oil pressure at max. rpm

4. Oil temperature at max. rpm

5. Each cylinder head temperature at max. rpm

6. EGT at max. RPM

7. Rpm drop during the spark plug check

8. Fuel consumption at max. rpm

9. Oil consumption

10. Pressure in the air manifold na konieczność ustalania właściwego ustawienia względem położenia wału korbowego.

Obsłudze technicznej wiele czasu zajmuje kontrola wszystkich połączeń śrubowych. Bezpośrednią przyczyną luzowania się nakrętek i śrub jest zjawisko relaksacji naprężeń. Eksploatatorzy powinni wiedzieć, że zjawisko relaksacji występuje nawet w silniku nieużytkowanym i pamiętać należy o skontrolowaniu momentów dokręcenia przed montażem silnika. Należy wziąć też pod uwagę, że wartości momentów zależą od materiału z jakiego zostały wykonane śruby, nakrętki i podkładki, dlatego nie wolno pochopnie stosować zamienników wykonanych z innego materiału niż ten określony przez wytwórcę silnika.

Opisane powyżej niektóre niekorzystne zjawiska mogące wystąpić podczas eksploatacji silnika i zasygnalizowane możliwości ich zapobiegania mają na celu przypomnienie personelowi służby inżynieryjno-lotniczej, na jakie elementy konstrukcji i praktyki obsługowej zwrócić uwagę, by utrzymać jak najdłuższy niezawodny czas pracy silnika na płatowcu.

\subsection{Warunki przedłużenia okresu międzyremontowego}

Doświadczenie eksploatacyjne w branży lotniczej prowadzi do pewności, że:

- ścisłe przestrzeganie podanych w instrukcjach, lub jeśli trzeba ustalenie, odpowiednich procedur operacyjnych,

- wysoki poziom kultury technicznej obsługi,

- prowadzenie monitorowania stanu technicznego silnika pozwalają na eksploatację silników tłokowych znacznie powyżej określonego przez producenta okresu międzyremontowego, bez ryzyka nagłej usterki podczas lotu.

Nie wszystkie silniki mogą mieć przedłużony resurs ze względu na znane w branży problemy, jak np. korozja i złuszczanie się wału rozrządu silników jednego z ich producentów, czy zmęczeniowe uszkodzenia wałów korbowych silników innego wytwórcy [5].

Obecnie nadzory lotnicze, jak już wspomniano, wymagają spełnienia wielu warunków i wykonania określonych dokumentacją producenta sprawdzeń, a także analiz niezbędnych do podjęcia decyzji o zwiększeniu okresu międzyremontowego silnika. Należą do nich:

a) sprawdzenie dokumentacji związanej z przeszłymi remontami,

b) analiza dokumentacji z przeglądów technicznych od ostatniego remontu,

c) jakość dokumentacji,

d) ocena okresu eksploatacji od ostatniego remontu ze szczególnym uwzględnieniem ewentualnych wypadków, zaniedbań itp.,

e) ocena rezultatów przeglądów wynikających z programu obsługi technicznej,

f) konfiguracja silnika (status modyfikacji, występowanie części PMA),

g) typ silnika (z wtryskiem paliwa, turbodoładowaniem, gaźnikowy),

h) typ śmigła napędzanego silnikiem,

i) rodzaj i przeznaczenie statku powietrznego, na którym jest zainstalowany silnik, 
Usage of the above-mentioned methodology in everyday maintenance practice, analysis of the results from subsequent inspections, adequate employment and equipment in maintenance and continuing airworthiness management organization is an evidence of their high technical culture and responsibility. In such circumstances extension of TBO will not have an adverse effect on flight safety.

\section{On condition maintenance of aviation piston engines}

In the preceding paragraphs existing rules of TBO extension were discussed.

Contemporary engineering expertise about the impact of external factors on performance and technical condition of the engine, knowledge of thermodynamic processes during engine operations, and available statistical data lead to the conclusion that some type of on condition maintenance is possible.

Rules of such exploitation have been developed by Institute of Aviation. They relate to both overhauled and actually in service engines. They are a compilation of manual's requirements and new, known but not utilized in current maintenance practice. They are:

- monitoring of the engine parameters adopted in the SMS

- continuing monitoring of the engine parameters from flight

- shape and size monitoring of the ferromagnetic particles in the engine oil

One of the important elements of safety management is making decisions on the basis of the characteristic factors adopted for its evaluation. These parameters, also known as indicators, are (or will be) defined by the operators, the continuing airworthiness management organizations or overhaul facilities in agreement with the competent authorities responsible for the national system of aviation safety.

For those indicators, established by different statistical methods, alert levels are defined, and their trend changes are observed. Introduction of the engine's on condition maintenance in any organization may be accepted provided they have documented technical assessments on the basis of the results of the maintenance inspections.

It is also necessary to carry out specific analysis for piston engines parameters from flight. It is important to track their trend changes. Parameters must be recorded from the beginning of the operation of the engine after installation on the airframe, after overhaul, after replacing the propeller from another aircraft. Parameters have to be recorded in the same range of engine rpm's both from cruise and climb. These parameters are:

1. Oil pressure

2. Oil temperature

3. Cylinder head temperature

4. EGT

5. Fuel consumption

6. Fuel pressure j) wyniki specjalnego przeglądu i próby silnika wykonane przed formalnym przedłużeniem resursu, bądź zgodą na jego zwiększenie.

Podstawowym przeglądem technicznym lotniczego silnika tłokowego jest obsługa 100-godzinna, podczas której wykonywanych jest wiele czynności określających jego stan techniczny; są to sprawdzenia:

1) ciśnienia różnicowego cylindrów,

2) ciśnienia sprężania cylindrów,

3) endoskopowa inspekcja stanu cylindrów i tłoków,

4) sprawdzenie stanu deflektorów powietrza w przedziale silnikowym,

5) filtra oleju,

6) korka magnetycznego (jeśli jest zainstalowany) w instalacji olejenia na obecność opiłków,

7) analiza spektralna oleju silnikowego,

8) zużycie oleju z lotu.

Punkty 5-8 wykonywane są z częstotliwością pięćdziesięciogodzinną.

Przegląd kończy specjalna próba silnika. Jej wyniki zapisywane są na formularzu i obejmują:

1) maksymalne sprowadzone prędkości obrotowe silnika,

2) ciśnienie oleju na biegu jałowym,

3) ciśnienie oleju na zakresie startowym,

4) temperaturę oleju na zakresie startowym,

5) temperaturę każdej głowicy cylindra na zakresie startowym,

6) temperaturę gazów wylotowych na zakresie startowym,

7) spadek prędkości obrotowej po kolejnym odłączaniu iskrowników,

8) zużycie paliwa na zakresie startowym,

9) zużycie oleju,

10) ciśnienie w kolektorze dolotowym powietrza.

Stosowanie przedstawionych w podpunkcie 4.2 zasad w codziennej praktyce eksploatacyjnej, analiza wyników sprawdzeń z kolejnych przeglądów, posiadanie odpowiedniego personelu przez organizacje obsługowe i zarządzania ciągłą zdatnością, a także posiadanie zaplecza technicznego i administracyjnego świadczą o ich wysokiej odpowiedzialności i kulturze technicznej. Wtedy przedłużenie czasu do pierwszego remontu i okresu międzyremontowego lotniczego silnika tłokowego nie spowoduje obniżenia poziomu bezpieczeństwa latania i nie powinno stwarzać jakichkolwiek zagrożeń.

\section{Eksploatacja według stanu technicznego lotniczego silnika tlokowego}

Omówiono już istniejące zasady umożliwiające przedłużanie okresu między remontami. Współczesna eksploatacyjna wiedza inżynierska o wpływie czynników zewnętrznych na parametry pracy silnika i jego stan techniczny, znajomość procesów termodynamicznych zachodzących podczas pracy silnika tłokowego, dostępne dane statystyczne prowadzą do wniosku, że możliwa jest eksploatacja niektórych typów lotniczych silników tłokowych według stanu technicznego. Zasady takiej eksploatacji opracowano w Instytucie Lotnictwa. Dotyczą one zarówno silników nowych lub po 
Lower and upper acceptable limit values should be set in the range in which they can be contained throughout engine life. Engineers should also observe the trend of their changes.

Piston aircraft engine after overhaul, or after replacement of the cylinders or cylinder for the first fifty hours of operation is in the process of forming. Therefore, the determination of the range which should contain the above parameter values should be carried out based on the data collected during the second fifty hours of engine operation, assuming their Gaussian distribution.

- parameters values should be recorded during each flight - for each parameter mean value should be counted

$$
\mathrm{P}_{\mathrm{m}}=\sum_{\mathrm{i}=1}^{\mathrm{n}} \mathrm{P}_{\mathrm{i}} / \mathrm{N}
$$

and the standard deviation:

$$
\sigma=\sqrt{\frac{\sum_{i=1}^{n}\left(P_{i}-P_{m}\right)^{2}}{N-1}}
$$

where: $\mathrm{N}$ - number of flights, $\mathrm{P}_{\mathrm{i}}$ - parameter value, $\mathrm{P}_{\mathrm{m}}-$ mean value.

For the next overhaul, replacement of the engine or propeller replacement, each parameter value should be within established range, from $\mathrm{m}+3 \sigma$ to $\mathrm{m}-3 \sigma$.

If any of the parameters value exceeds the limit cause of that has to be determined immediately.

A similar procedure should be carried out for the results of spectrographic analysis of oil. In this case, however, setting maximum limits for the content of given particles in the oil shall be determined after four subsequent analyses in the same laboratory.

Observing the trend of characteristic elements of quantitative changes in engine oil is important, as some manufacturers are suggesting that limits can be established by operator individually for each engine of the same type. While others provide limits that are far from values observed during standard operation.

\section{Supervised exploitation of IO-240-A/B engines}

In order to verify established rules of the on condition maintenance, at present supervised exploitation of four IO240-A/B engines, installed on Diamond DA-20-C1aircraft is being carried out.

IO-240-A/B (A and B differ only by type of the fuel injectors) manufactured by Continental Motors, Inc. is four cylinder, four stroke reciprocating aircraft engine with horizontally opposed cylinders, fuel injectors and wet sump. Cylinder displacement is 240 cubic inches $\left(4000 \mathrm{~cm}^{3}\right)$.

This engine at compression 8.5 has power $125 \mathrm{KM}(93$ $\mathrm{kW}$ ), speed $2800 \mathrm{rpm}$, at sea level, standard atmosphere conditions. It has been certified for Avgas $100 \mathrm{LL}$ and 100 fuels. IO-240 found use on Diamond DA-20-C1, Eagle Aircraft 150 B, Rans S-16 Shekari, Roko Aero NG4. In Poland the most popular of the engines are DA-20 -C1. Two types of propellers can be installed: Sensenich W69K-63 and MT-175R 150-2Ca. remoncie, jak i tych będących w eksploatacji. Są one kompilacją rekomendowanych instrukcjami producentów zadań obsługowych i proponowanych nowych, niestosowanych w dotychczasowej praktyce. Należą do nich:

- monitorowanie parametrów silnikowych przyjętych w zarządzaniu bezpieczeństwem,

- ciągłe monitorowanie parametrów z lotu przyjętych do oceny stanu technicznego (Engine Condition Monitoring),

- pomiar i monitorowanie wielkości cząstek ferromagnetycznych w oleju silnikowym.

Jednym z ważniejszych elementów zarządzania bezpieczeństwem jest podejmowanie decyzji na podstawie charakterystycznych wielkości przyjętych do oceny silnika. Parametry te, nazywane też wskaźnikami, określone są (bądź będą) przez operatorów, organizacje zarządzania ciągłą zdatnością lub remontowe w uzgodnieniu z kompetentnymi władzami odpowiedzialnymi za krajowy system bezpieczeństwa lotniczego. Dla tych ustalonych różnymi metodami statystycznymi wskaźników przyjmuje się poziomy alarmowe, a także obserwuje trendy ich zmian.

Wprowadzenie w organizacji eksploatacji silników według stanu technicznego może być zaakceptowane pod warunkiem posiadania przez tę organizację lub operatora eksploatacyjnej dokumentacji oceny stanu technicznego na podstawie wyników przeglądów technicznych. Konieczne jest również prowadzenie analizy charakterystycznych dla silników tłokowych parametrów ich pracy w locie. Ważne jest śledzenie trendu ich zmian. Należy prowadzić zapisy wartości tych wielkości od początku pracy silnika po jego zabudowie na płatowcu po remoncie, po wymianie śmigła lub przebudowie $\mathrm{z}$ innego statku powietrznego. Zapisów parametrów należy dokonywać w tym samym przedziale prędkości obrotowych zarówno z lotu poziomego, jak i wznoszenia. Parametrami tymi są:

1) ciśnienie oleju,

2) temperatura oleju,

3) temperatura głowic cylindrów,

4) temperatura gazów wylotowych,

5) zużycie paliwa,

6) ciśnienie paliwa.

Należy wyznaczyć dolną i górną dopuszczalną granicę wartości w przedziale, w którym mogą się zawierać przez cały okres eksploatacji. Należy również obserwować trendy ich zmian.

Tłokowy silnik lotniczy po remoncie, po wymianie cylindrów bądź cylindra przez pierwszych pięćdziesiąt godzin użytkowania podlega procesowi formowania. Dlatego wyznaczenie przedziału, w którym powinny zawierać się wartości wymienionych parametrów przeprowadzić należy na podstawie zebranych danych w czasie drugich pięćdziesięciu godzin pracy silnika, zakładając, że przyjmują rozkład normalny.

Należy odnotowywać wartości tych parametrów podczas każdego lotu, a następnie dla każdego z nich policzyć wartość średnią - wzór (1) i odchylenie standardowe - wzór (2) gdzie: $\mathrm{N}$ - liczba lotów, $\mathrm{P}_{\mathrm{i}}$ - wartość parametru, $\mathrm{P}_{\mathrm{m}}$ - średnia wartość parametru. 
The operational upper limit

\begin{tabular}{l} 
The parameter values recorded every next 100 hours \\
The parameter values recorded after The average value \\
m-36 for 50 hours \\
\hline
\end{tabular}

Fig. 2. Example of graphical representation of the value changes for one of the operational parameters of the engine in flight. The operational upper limit is greater than the upper limit of the diagnostic $(m+3 \sigma)$

Rys. 2. Przykład graficznego przedstawienia zmian wartości jednego z parametrów pracy silnika odnotowanego w locie, gdzie ograniczenie eksploatacyjne jest większe niż górna granica tolerancji diagnostycznej $m+3 \sigma$

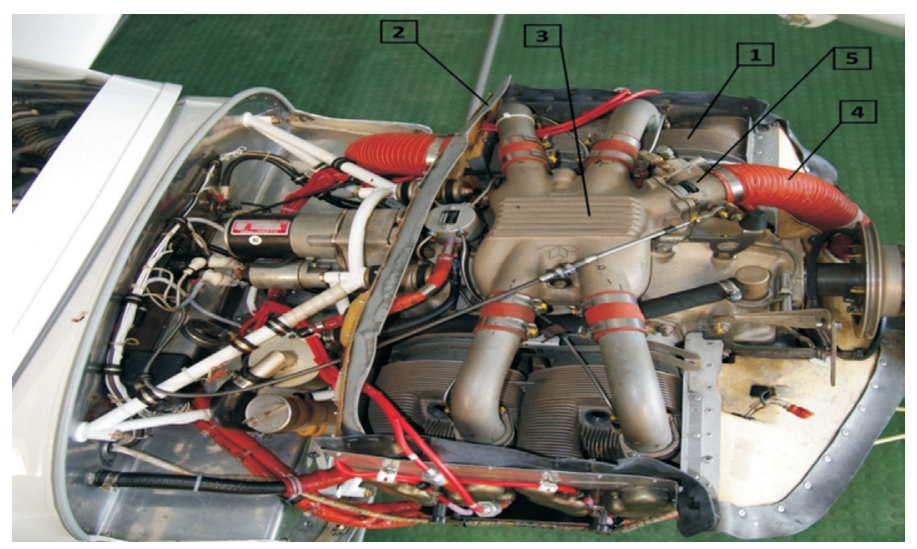

Fig. 3. IO-240-B engine seen from above: 1 - cylinder, 2 - baffles, 3 - manifold of the air supplied to the cylinders, 4 - air supply hose, 5 - throttle

Rys. 3. Silnik IO-240-B widziany z góry: 1 -cylinder, 2 -deflektor powietrza, 3 - kolektor powietrza doprowadzanego do cylindrów, 4-przewód doprowadzania powietrza do silnika, 5 - przepustnica

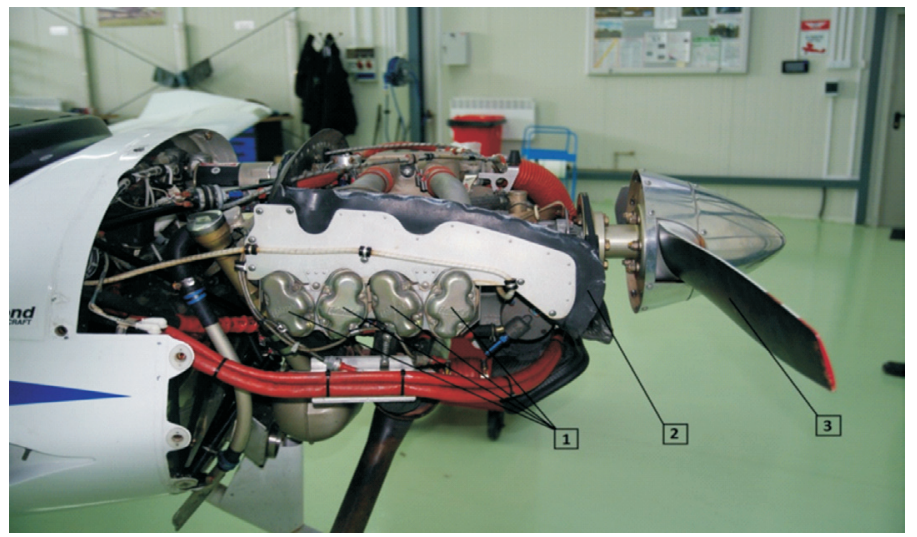

Fig. 4. The propulsion system of the Diamond DA20-C1 "Katana" aircraft: 1 - the valve cover, 2 - baffles, 3 - propeller

Rys. 4. Zespót napędowy samolotu Diamond DA20-C1 „Katana”: 1-pokrywy zaworów, 2 - deflektor powietrza, 3 -śmigło
Do następnego remontu bądź przebudowy silnika, czy wymiany śmigła wartość każdego z parametrów powinna zawierać się w wyznaczonym dla każdego z nich przedziale od $m-3 \sigma$ do $m+3 \sigma$ (rys. 2 ).

Jeżeli jakikolwiek z parametrów przekroczy graniczną wartość, należy określić przyczynę takiego stanu.

Podobną procedurę należy przeprowadzić w odniesieniu do analizy spektralnej oleju. Wtedy jednak wyznaczenia dopuszczalnych granic zawartości danego pierwiastka w oleju dokonać należy po przeprowadzeniu kolejnych czterech badań w tym samym laboratorium.

Obserwacja trendu zmian ilościowych charakterystycznych pierwiastków w oleju silnika jest istotna, ponieważ niektórzy producenci silników sugerują wyznaczenie dopuszczalnych wielkości indywidualnie przez każdego operatora, a podane przez innych wytwórców graniczne wartości wielokrotnie przewyższają te obserwowane w eksploatacji. Metodyka opracowana w Instytucie Lotnictwa nakazuje badania sześciu pierwiastków, a mianowicie: żelaza (Fe), glinu (Al), chromu (Cr), miedzi (Cu), krzemu (Si) i ołowiu $(\mathrm{Pb})$. Istotne znaczenie w ocenie postępującego, a nawet katastroficznego uszkodzenia silnika ma monitorowanie w oleju wielkości i ilości cząstek metalicznych w postaci włosków lub łusek. Producenci lotniczych silników tłokowych nie podają ani granicznej ich wielkości, ani dopuszczalnej ilości tych zanieczyszczeń.

\section{Eksploatacja nadzorowana silników IO-240-A/B}

W celu weryfikacji przyjętych zasad eksploatacji lotniczych silników tłokowych według stanu technicznego prowadzona jest eksploatacja nadzorowana czterech silników IO-240-A/B zabudowanych na samolotach Diamond DA20-C1 Katana tego samego operatora.

Silnik IO-240-A/B (wersja A od B różni się tylko typem wtryskiwaczy paliwowych) firmy Continental Motors, Inc. jest czterosuwowym, czterocylindrowym zespołem napędowym w układzie bokser („O” - horizontally opposed cylinders) o objętości skokowej około $4000 \mathrm{~cm}^{3}$ (240 cubic inches) z mokrą miską olejową z wtryskiem paliwa („I”- fuel injected). Silnik ten dla maksymalnego stopnia sprężania wynoszącego 8,5 osiąga moc $93 \mathrm{~kW}$ (125 KM) przy prędkości obrotowej wynoszącej $2800 \mathrm{obr} / \mathrm{min}$ w warunkach atmosfery wzorcowej na poziomie morza. Certyfikowany jest na paliwa lotnicze tzw. Avgas 100 LL (niebieski) i 100 (zielony) o max. zawartości czteroetylku ołowiu odpowiednio 0,56 g/1 i 1,12 g/l (w Polsce dostępna jest benzyna lotnicza B91/115 o zawartości 1,8 g/l czteroetylku ołowiu, zabarwiana na zielono; trzeba więc uważać, by nie pomylić paliw o tym samym kolorze).

IO-240 znalazły zastosowanie jako napęd samolotów Diamond DA20-C1, Eagle Aircraft 150B, Rans S-16 Shekari, Roko Aero NG4. W Polsce najpopularniejszym z wymienionych statków powietrznych jest Diamond Katana. Silnik ten, zabudowany na płatowcu Diamond, 
Figure 3 shows view of the engine from the top, while figure 4 shows photo of the same power train and MT propeller viewed from the right side.

Publications for this engine are as follows:

1. IO-240-A/B Maintenance and Overhaul Manual (M-6)

2. Installation and Operation Manual (OI-6)

3. S-20/S-200 Magneto Service Manual (X42002)

4. Parts Catalog

5. Service Documents e.g. SB's, SID's

Supervised exploitation is designated to conform to established criteria and methods for the evaluation of the engine technical condition with the field operations. Engines were qualified to the program after evaluation of the subsequent inspections results and their failures analysis. They have already achieved 1152, 1485, 764, 443 hours respectively.

For both cruise and climb new engine parameters tolerances were assigned.

Figure 5 shows values of engine rpm's during cruise. Engine rpm's were in the narrow range when flight parameters have been registered. It can be assumed that engine load was almost the same during each registration.

On the figures from 6 to 8 values of the new operational limits are shown as examples. Figures with index "a" are representing their corresponding Gaussian distribution.

a)

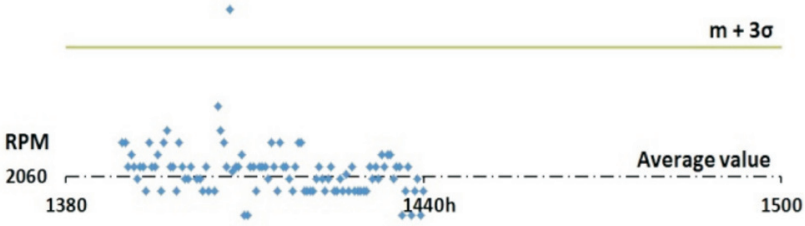

flying hours: $1444 \mathrm{~h}$

b)
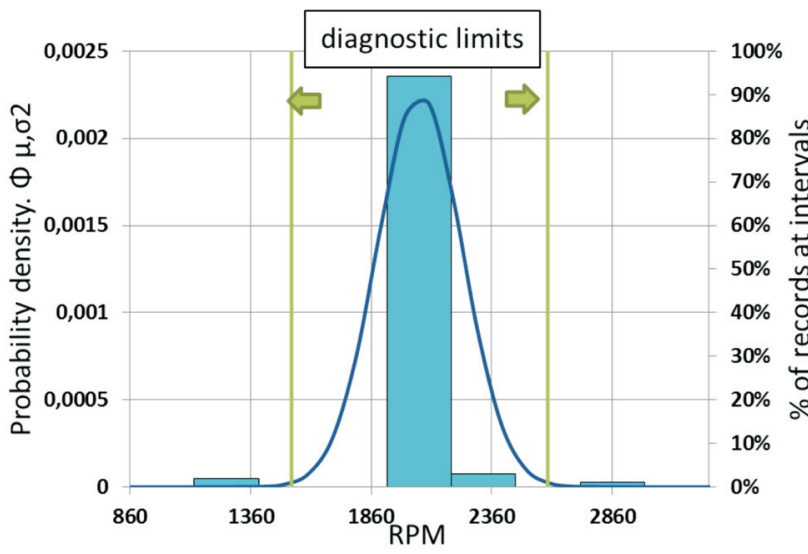

Fig. 5. Engine rpm during the flight: a) values, b) Gaussian distribution, the IO-240-B engine, installed on DA20-C1 "Katana" aircraft

Rys. 5. Prędkość obrotowa podczas przelotu a) wartości chwilowe, b) rozklad Gaussa, silnik IO-240-B, samolot DA20-C1 „,Katana”, może współpracować ze śmigłami: Sensenich W69EK-63 i niemieckim MT-175 R 150-2Ca.

Na rysunku 3 przedstawiono zespół napędowy widziany z góry, natomiast na rys. 4 - ten sam zespół napędowy samolotu Diamond ze śmigłem MT widziany z prawej strony.

Obowiązująca dokumentacja dla tego typu silnika obejmuje:

1. „Instrukcję obsługi technicznej i remontu silników serii IO-240" (M-6).

2. „Instrukcję zabudowy i użytkowania” (OI 6).

3. „Instrukcję serwisową iskrowników S 20/S-200” (X42002).

4. Katalog części zamiennych.

5. Dokumenty eksploatacyjne, jak biuletyny serwisowe, czy tzw. SID (Service Information Directive).

Eksploatacja nadzorowana ma za zadanie skonfrontowanie kryteriów i sposobów oceny stanu technicznego silnika przyjętych w założeniach programu z rzeczywistą eksploatacją.

Silniki zakwalifikowano do eksploatacji nadzorowanej po analizie rezultatów ich kolejnych przeglądów i ocenie

a)

Operational limit $=215^{\circ} \mathrm{C}$

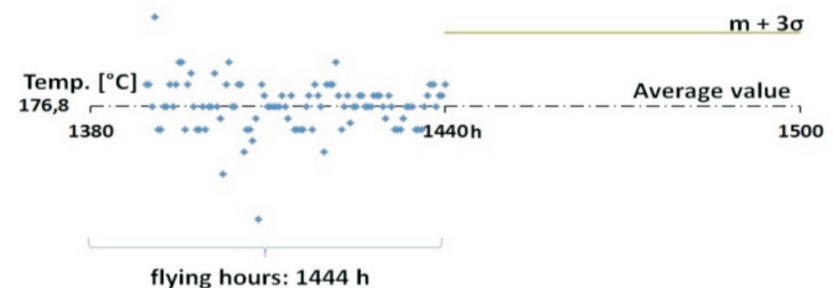

b)

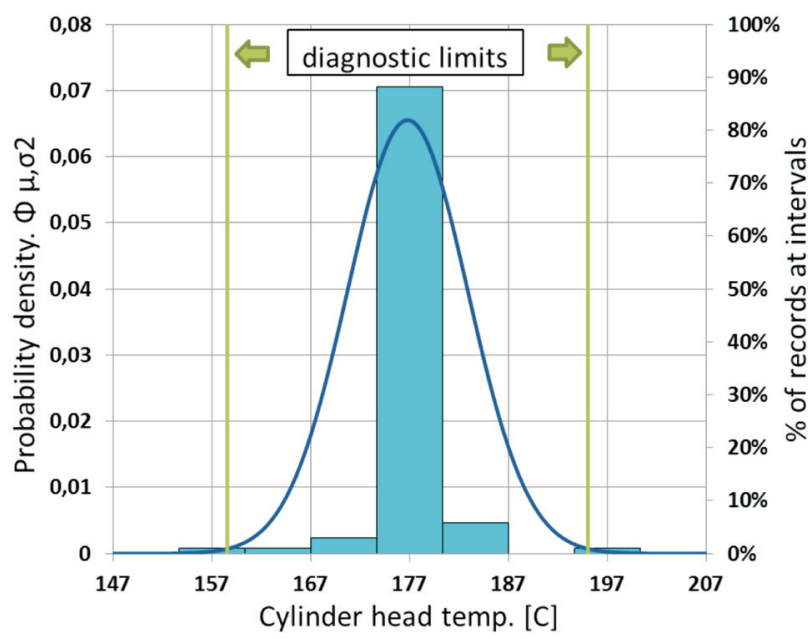

Fig. 6. Cylinder head temperature during the flight: a) values, b) Gaussian distribution, the IO-240-B engine, installed on DA20-C1 "Katana" aircraft

Rys. 6. Temperatura głowic cylindrów podczas przelotu: a) wartości chwilowe, b) rozkład Gaussa, silnik IO-240-B, samolot DA20-C1 "Katana" 
a)

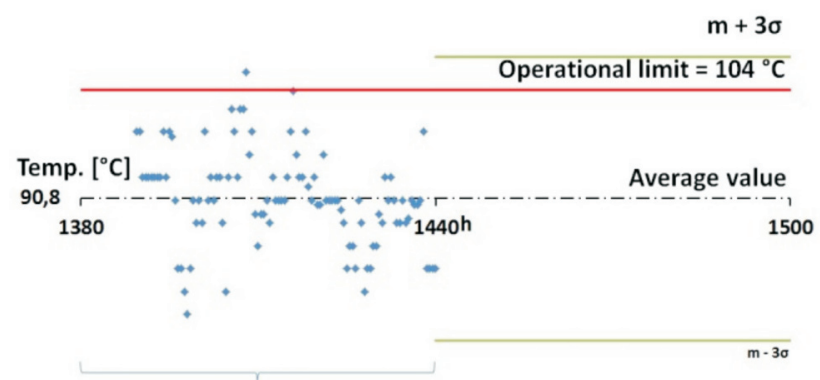

flying hours: $1444 \mathrm{~h}$

b)

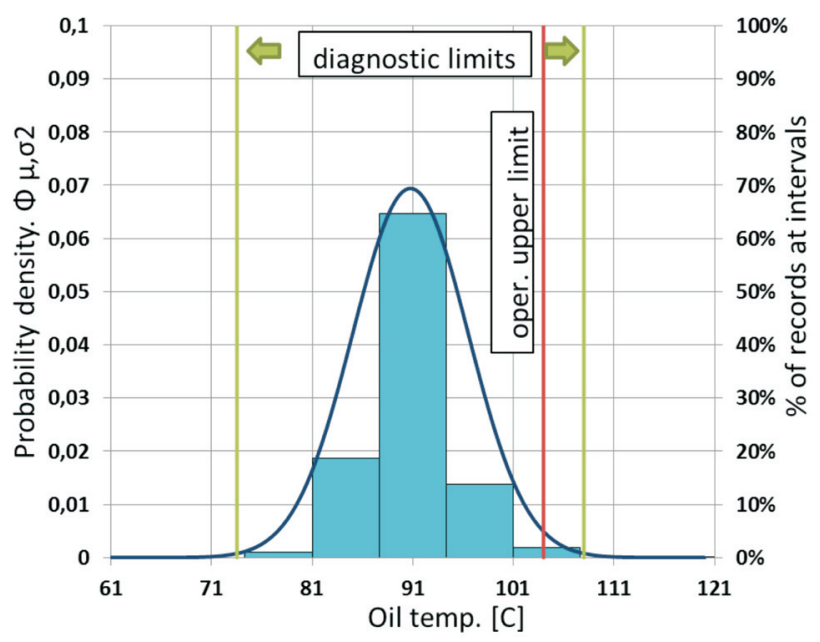

Fig. 7. Oil temperature during the flight: a) values, b) Gaussian distribution, the IO-240-B engine, installed on DA20-C1 "Katana" aircraft

Rys. 7. Temperatura oleju podczas przelotu: a) wartości chwilowe, b) rozktad Gaussa, silnik IO-240-B, samolot DA20-C1 „Katana”

Figures 7 and 8 are showing oil temperatures of the engines installed on the two different aircraft.

Such big difference between indicated oil temperatures of these two engines was difficult to understand.

After thorough analysis of both oil systems, it was found that one of the aircraft was equipped with smaller oil cooler, This is only the case since the new diagnostic tolerance limit is higher than the limit set in the manual. In this case obligatory limit is same like in the manual.

Identical steps were established for the climb. During climb engine is more loaded than during cruise. It is important to observe power train behaviours during both flight phases.

As it was mentioned in Section 5, the spectrographic analysis of six elements in the engine oil were carried out. It was assumed that after four consecutive, performed every 50 hours analyses, carried out in the same laboratory, permissible limit of the element amount in the oil can be determined.

For example, Fig. 9 and Fig. 10 show assigned limits of iron and lead for a specific engine. a)

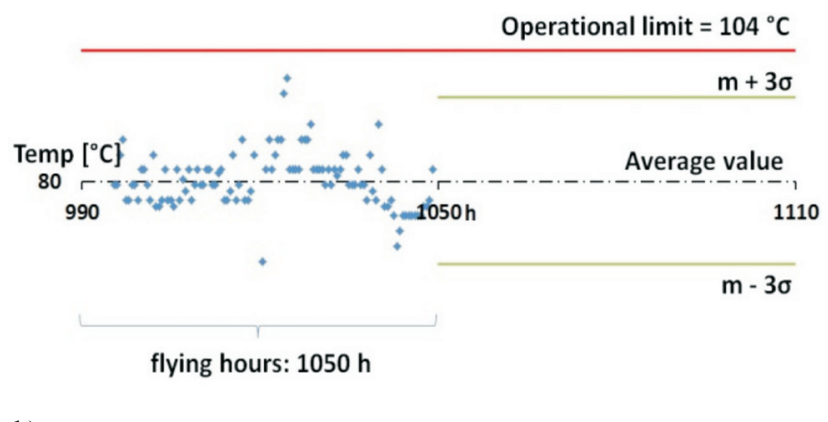

b)

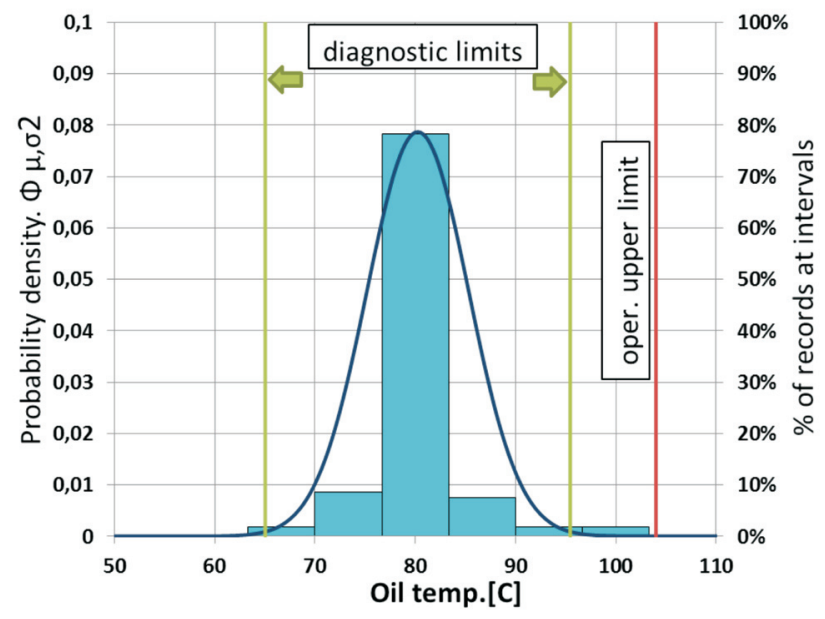

Fig. 8. Oil temperature during the flight: a) values, b) Gaussian distribution, the IO-240-B engine, installed on DA20-C1 "Katana" aircraft

Rys. 8. Temperatura oleju podczas przelotu: a) wartości chwilowe, b) rozkład Gaussa, silnik IO-240-B, samolot DA20-C1 „,Katana”,

usterkowości w procesie użytkowania. Osiągnęły one już nalot, kolejno 1152, 1485, 764, 443 godziny. Zarówno z lotu, jak i z wznoszenia wyznaczono dla nich granice tolerancji diagnostycznej dla przyjętych parametrów.

Prędkości obrotowe (rys. 5), dla których dokonywano zapisów parametrów pracy silnika zawierały się w bardzo wąskim zakresie. Można przyjąć, że ich rejestracji dokonano przy tych samych obciążeniach zespołu napędowego.

Na rysunkach od 6 do 8 przedstawiono przykładowo wartości nowych ograniczeń eksploatacyjnych. Rysunki 6a-8a przedstawiają odpowiadające im parametry rozkładu normalnego.

$\mathrm{Na}$ rysunkach 7 i 8 przedstawiono wartości nowych ograniczeń temperatury oleju silników zabudowanych na różnych płatowcach. Znaczne różnice wielkości zarówno wartości średniej, jak i górnej granicy tolerancji diagnostycznej pomiędzy dwoma silnikami były trudne do wythumaczenia.

W wyniku skrupulatnej analizy instalacji olejenia obydwu zespołów napędowych stwierdzono, że na jednym płatowcu zabudowana jest chłodnica oleju o mniejszej powierzchni niż na drugim. Dlatego, jako jedyny przypadek, obliczone ograniczenie (rys. 7) przewyższa podane przez 


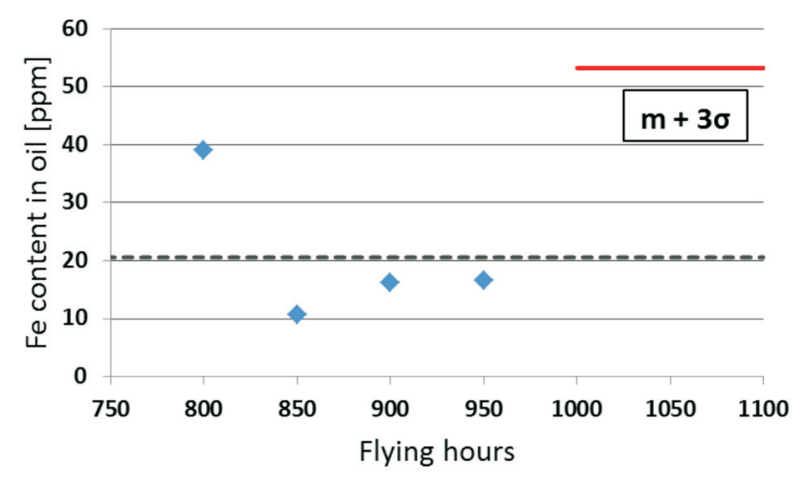

Fig. 9. The content of iron in the oil of IO-240-B engine installed on the DA20-C1 "Katana" aircraft.

Rys. 9. Zawartość żelaza w oleju silnika IO-240-B zabudowanego na samolocie DA20-C1 „Katana”

Evaluation of the content of $\mathrm{Fe}, \mathrm{Cr}, \mathrm{Cu}$, and $\mathrm{Al}$ in the engine oil is carried out for obvious reasons arising from the materials used to manufacture engine components.

Examination of the Si content was introduced to assess the environmental conditions in which the aircraft and engine is operated.

Low content of lead, however, can inform about the quality and type of fuel used. Therefore, it is important to know lower limit of the amount of this element.

Increasing of the engine operating time is the cause of its deterioration, especially of friction elements. Therefore, in addition to the spectrographic analysis each time oil must be exchanged, it is necessary to examine not only the metal particles that adhere to the filter, but also those in the drained oil.

Such a procedure is particularly important when there is no magnetic plug in the lubrication system.

In the photograph (Fig. 11) shows magnet with ferromagnetic particles taken from drained engine oil. In the photograph (Fig. 12), the same elements on graph paper.

Because there are no standards defined by manufacturers for size limit and the number of large particles in the engine oil, extremely detailed documentation at every oil change should be carried out.

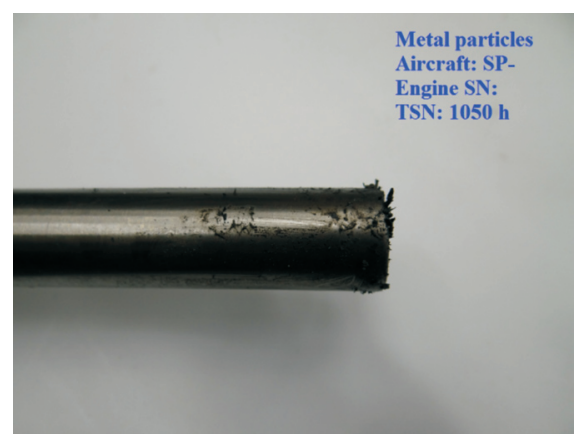

Fig. 11. View of the magnet after immersion in the oil taken from the IO 240-B engine, after fifty hours of operation

Rys. 11. Widok magnesu po zanurzeniu $w$ zlanym oleju po pięćdziesięciu godzinach pracy silnika IO 240-B

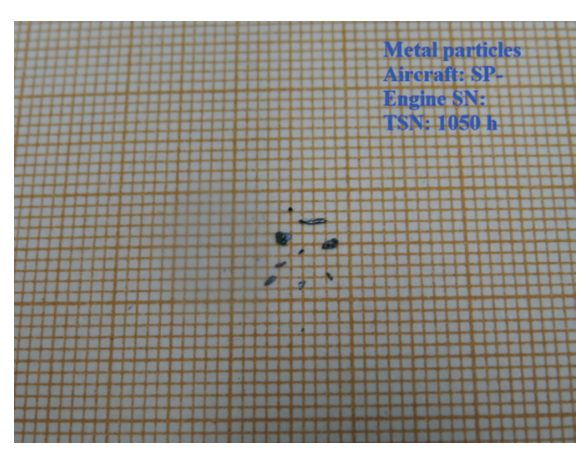

Fig.12. Ferromagnetic particles that were present in the oil after fifty hours of operation of the IO240-B engine, installed on the aircraft DA20-C1 "Katana"

Rys. 12. Cząstki ferromagnetyczne obecne w oleju po pięćdziesięciu godzinach pracy silnika IO-240-B zabudowanego na samolocie DA20-C1 ,Katana”,

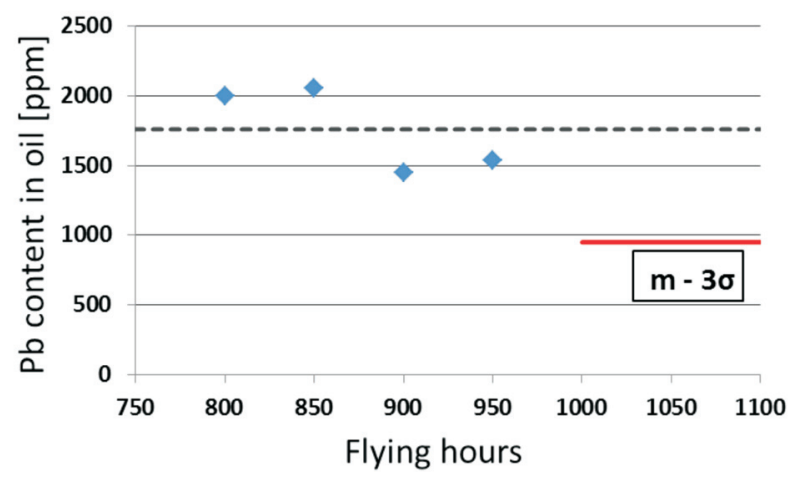

Fig. 10. The content of lead in the oil of IO-240-B engine installed on the DA20-C1 "Katana" aircraft

Rys. 10. Zawartość ołowiu w oleju silnika IO-240-B zabudowanego na samolocie DA20-C1 „Katana”

producenta. Wtedy obowiązuje to wynikające $\mathrm{z}$ instrukcji eksploatacji tego silnika.

Identyczne postępowanie jak dla lotu poziomego obowiązuje dla wznoszeniu, podczas którego obciążenie silnika jest większe, dlatego metodyka wymaga monitorowania parametrów pracy silnika podczas obu faz lotu samolotu.

Jak podano w rozdz. 5, prowadzona jest analiza spektralna zawartości sześciu pierwiastków w oleju silnikowym. Przyjęto, że po czterech kolejnych, wykonywanych co 50 godzin, badaniach przeprowadzanych w tym samym laboratorium, wyznaczana jest granica dopuszczalnej ilości pierwiastka w oleju.

Przykładowo, rysunki 9 i 10 przedstawiają wyznaczone granice dopuszczalnych ilości żelaza i ołowiu dla konkretnego silnika.

Ocena zawartości $\mathrm{Fe}, \mathrm{Cr}, \mathrm{Cu}$, i Al w oleju silnikowym przeprowadzana jest z oczywistych względów, wynikających z materiałów użytych do wyprodukowania elementów silnika.

Badanie zawartości Si wprowadzono do oceny warunków zapylenia środowiska, w którym eksploatowany jest samolot i silnik.

Mała zawartość ołowiu może świadczyć o jakości i rodzaju stosowanego paliwa, dlatego tak istotna jest dolna granica eksploatacyjna ilości tego pierwiastka.

Zwiększający się podczas eksploatacji czas pracy silnika jest przyczyną wzrostu jego zużycia, szczególnie elementów trących. $Z$ tego względu oprócz analizy spektralnej oleju należy przy każdej jego wymianie dokonać analizy nie tylko cząstek metalicznych osadzających się na filtrze, lecz także tych zawartych w zlanym z silnika oleju. Procedura taka jest szczególnie ważna, gdy $\mathrm{w}$ instalacji olejenia silnika brakuje tzw. korka magnetycznego. $\mathrm{Na}$ rysunku 11 pokazano cząstki ferromagnetyczne przyciągnięte przez 
On condition based maintenance includes all required tasks from the manuals. One of them - BSI is particularly important in evaluation of the engine cylinders condition.

This inspection is carried out to check the head of the cylinder, its wall and the upper surface of the piston. Detection of any cracks, missing material, excessive amounts of carbon deposits, or traces of burning requires immediate action involving the exchange of the cylinder.

It enables avoidance of a costly repair, and most of all, potential faults during the flight. Picture (Fig. 13) shows the upper surface of the piston, the next (Fig. 14) shows the surface condition of valves and valve seats.

The results of subsequent engine BSI's must be kept, to be able to compare the intensity of the possible deterioration of the cylinders. Similar requirement applies to documented results of all the activities listed in section 4.2.

\section{Conclusions}

Results of supervised exploitation confirm the assumptions made for the program of on condition maintenance. It should be emphasized that each engine must be treated individually and it is not possible to average the various constraints in such a way that they can be the same for different types of engines. This is due to the fact that at least various types of propellers or the various components in key systems are installed (e.g. earlier mentioned oil cooler).

The next step in improving the analysis of operating parameters of the engine will be FDR installation on the airframe, which will allow elimination of the pilot's reading errors and examination of the changes in the parameters during the entire flight will be possible (whether in the certain time not exceeding the permissible values).

The positive outcomes of the results from the recorder for engine analysis will enable the extension of FDR capabilities for the aircraft flight parameters, which will lead to the introduction of objective flight control. Thus improve the safety of flying.

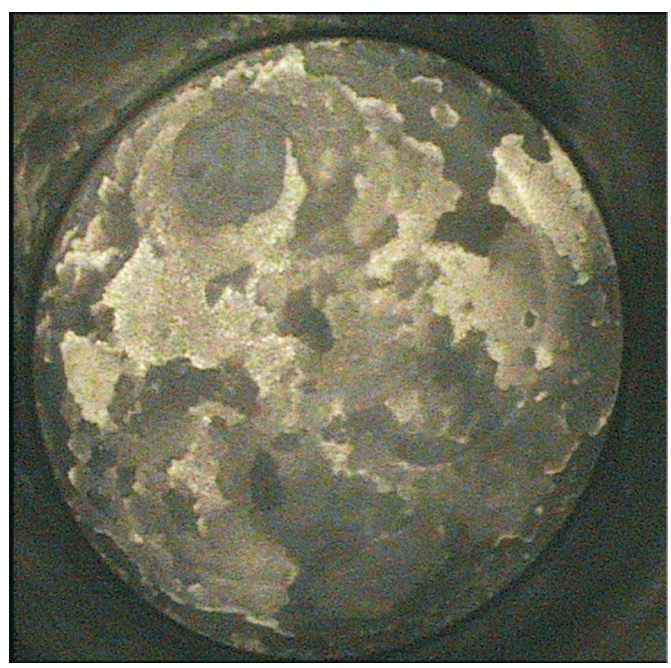

Fig. 13. View of the no 1 piston inside the cylinder of the IO-240-B engine, installed on the DA20-C1 "Katana" aircraft

Rys. 13. Tłok cylindra nr 1 silnika IO-240-B zabudowanego na samolocie DA20-C1 „Katana” zanurzony magnes w naczyniu ze zlanym z silnika olejem, a rys. 12 te same elementy na papierze milimetrowym. Ponieważ brak jest jakichkolwiek norm producentów określających dopuszczalną wielkość i liczbę dużych cząstek w oleju silnikowym, należy prowadzić wyjątkowo skrupulatne ich dokumentowanie przy każdej wymianie oleju.

Eksploatacja według stanu technicznego obejmuje wszystkie wymagane instrukcjami producentów czynności. Jedną z nich jest bardzo ważna dla oceny stanu technicznego silnika endoskopowa kontrola stanu cylindrów. Podczas niej przeprowadzane jest sprawdzenie głowicy, ściany cylindra i górnej powierzchni tłoka. Wykrycie jakichkolwiek pęknięć, ubytków materiału, nadmiernej ilości nagaru, śladów przepaleń wymaga podjęcia natychmiastowych czynności związanych $\mathrm{z}$ wymianą cylindra. Unika się $\mathrm{w}$ ten sposób kosztownego remontu, a przede wszystkim potencjalnej usterki w trakcie lotu. Rysunek 13 przedstawia górną powierzchnię tłoka, a rys. 14 - stan powierzchni zaworów i ich gniazd.

Wyniki kolejnych przeglądów endoskopowych silnika należy przechowywać, by móc porównać intensywność ewentualnego pogarszania się stanu cylindrów. Podobne wymaganie dotyczy dokumentowania wyników wszystkich czynności wymienionych w podpunkcie 4.2.

\section{Podsumowanie}

Dotychczasowe wyniki eksploatacji nadzorowanej potwierdzają założenia przyjęte w programie wprowadzenia eksploatacji lotniczych silników tłokowych według stanu technicznego.

Podkreślenia wymaga to, że każdy silnik należy traktować indywidualnie i nie jest możliwe uśrednienie poszczególnych ograniczeń w taki sposób, by mogły być jednakowe dla poszczególnych typów silników. Wynika to choćby ze współpracy z różnymi typami śmigieł, czy zainstalowania różnych podzespołów w ważnych instalacjach (jak np. wspomniana chłodnica oleju).

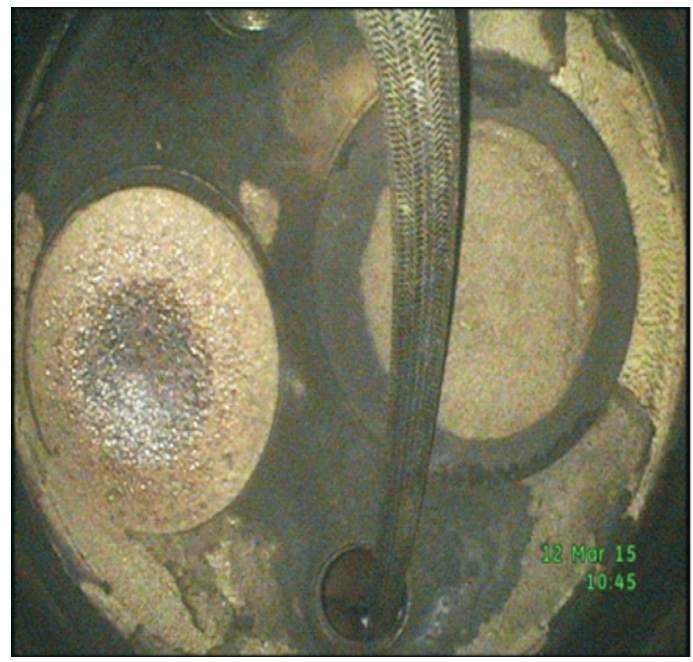

Fig. 14. View of the no 1 cylinder head of the IO-240-B engine, installed on the DA20-C1 "Katana" aircraft

Rys.14. Głowica cylindra nr 1 silnika IO-240-B zabudowanego na samolocie DA20-C1 „Katana” 
Despite the fact that the on condition maintenance requires additional tasks and analysis, it enables the detection of dangerous fault symptoms at an early stage. Operator avoids potential incident and related economic effects, also reduces the direct engine operating costs per flight hour.

"... The suggestion to introduce the method of operation of reciprocating engines according to the principles for assessment of the current technical condition into our national aviation, I feel is fully justified and I strongly support it.

The effects of the implementation of this method to the maintenance practice of aircraft piston engines has not only a positive economic impact for general aviation operators, but also intangible, like improvement of the flight safety, technical culture and sense of responsibility of aviation technical staff and pilots..."

Professor Stefan Szczeciński

\section{Nomenclature/Skróty i oznaczenia}

BSI borescope inspection/inspekcja endoskopowa

CAA Civil Aviation Authority/Cywilny Nadzór Państwowy

CAP Civil Aviation Publications/Publikacje Nadzoru Państwowego

FDR flight data recorder/pokładowy rejestrator parametrów lotu

NAA National Aviation Authority/Narodowy Nadzór Lotniczy

SID service information directive/informacyjna dyrektywa serwisowa

SB service bulletin/biuletyn serwisowy

TBO time between overhaul/czas między kolejnymi remontami silnika
Innym krokiem w udoskonaleniu analizy parametrów pracy silnika będzie zainstalowanie na płatowcu pokładowego rejestratora parametrów (obecnie w fazie prób). Wyeliminowane zostaną możliwe błędy odczytu przez pilota i możliwe będzie przeanalizowanie zmian parametrów podczas całego lotu (czy w jakimkolwiek momencie nie nastąpiło przekroczenie ich dopuszczalnych wartości).

Pozytywne wyniki zastosowania rejestratora na potrzeby analiz silnikowych umożliwią rozszerzenie zapisów z lotu na parametry samolotu, co doprowadzi do zobiektywizowania kontroli lotów. Tym samym poprawi bezpieczeństwo latania.

Pomimo tego, że eksploatacja według stanu technicznego wymaga wykonywania dodatkowych czynności i analiz, to jednak pozwala wcześnie wykryć symptomy powstania niebezpiecznej usterki. Operator uniknie potencjalnego zdarzenia lotniczego i związanych z nim skutków ekonomicznych. Taki sposób eksploatacji redukuje również bezpośrednie koszty obsługi silnika na godzinę lotu.

„....Sugestię wprowadzenia metody eksploatacji silników tłokowych wedtug zasady oceny biezacego stanu technicznego $w$ naszym krajowym w lotnictwie uważam za w petni uzasadniona i goraco ja popieram.

Skutki wdrożenia tej metody do praktyki użytkowania lotniczych silników tlokowych to nie tylko wymierne pozytywne skutki ekonomiczne dla operatorów lotnictwa ogólnego, ale i niewymierne - jak podniesienie poziomu bezpieczeństwa latania i kultury technicznej oraz poczucia odpowiedzialności stużb naziemnych lotnictwa i pilotów...”.

Prof. dr hab. inż. Stefan Szczeciński

\section{Bibliography/Literatura}

[1] Dzierżanowski P., Łyżwiński M., Szczeciński S. Silniki tłokowe. WKŁ, Warszawa 1981.

[2] Kostia T. Silniki lotnicze. Wydawnictwo MON, Warszawa 1953.

[3] Szczeciński S. Lotnicze silniki tłokowe. Wydawnictwo MON, Warszawa 1969.

[4] Annex 19 to the Convention on International Civil Aviation Safety Management. International Civil Aviation Organization, First Edition, July 2013.
[5] Engine overhaul life and operating on - condition. Light Aircraft Association, TL 2.23, 2011.

[6] Lycoming Service Instruction, No. 1009 AV, 2013.

[7] Mandatory requirements for airworthiness CAP 747. Safety Regulation Group, Civil Aviation Authority, 2012.

[8] Safety management manual. International Civil Aviation Organization, Doc. 9859 AN/474, Third edition, 2012.

[9] Service Letter No, L171. Textron Lycoming, 1971.

[10] Tips on engine care. Continental Motors Inc, TEC 1, 2011.
Paweł Głowacki, DEng. - Assistant professor in the Center of Space Technologies of the Institute of Aviation.

Dr inz. Pawel Glowacki-adiunkt w Centrum Technologii Kosmicznych Instytutu Lotnictwa. e-mail: pawel.glowacki@ilot.edu.pl

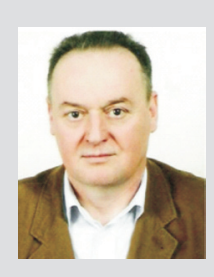

Borys Lukasik, MEng. - Research associate in the Center of Space Technologies of the Institute of Aviation.

Mgr inż. Borys Lukasik-asystent w Centrum Technologii Kosmicznych, Instytutu Lotnictwa. e-mail: borys.lukasik@ilot.edu.pl 